\title{
PERAN PEMERINTAH KABUPATEN NUNUKAN DALAM PENANGANAN IDENTITAS KEWARGANEGARAAN GANDA DI KECAMATAN LUMBIS OGONG KALIMANTAN UTARA
}

\author{
Matheus Gratiano Mali, Suwarjo Suwarjo, Tedy Roy Amos \\ Program Studi Ilmu Administrasi Publik, Universitas Widya Mataram \\ Email : theogratiano_88@yahoo.com
}

\begin{abstract}
Abstraksi
Penelitian ini adalah untuk mengetahui peranan Pemerintah Kabupaten Nunukan dalam menangani identitas kewarganegaraan ganda di Kecamatan Lumbis Ogong Kalimantan Utara dan untuk mengetahui hambatan dan kendala yang dihadapi dalam penanganan identitas kewarganegaraan ganda di pebatasan Kecamatan Lumbis Ogong Kalimantan Utara. Penelitian ini berlokasi di Desa Sumentobo Kecamatan Lumbis Ogong. Penulis memperoleh data dengan langsung dengan narasumber, memberikan pertanyaan serta mengambil data langsung dari perpustakaan yang relevan, literatur, dokumen desa/kecamatan Lumbis Ogong serta peraturan perundang-undangan yang berkaitan dengan masalah tersebut.

Dari hasil penelitian yang telah dilakukan, diperoleh kesimpulan 1) Peran pemerintah Kabupaten Nunukan dalam penanganan identitas kewarganegaraan ganda yaitu dengan melakukan inovasi program si pelanduk kilat yaitu sistem pelayanan administrasi kependudukan untuk wilayah pedalaman dan perbatasan, melaksanakan program jemput bola yang berada di wilayah perbatasan Indonesia-Malaysia, menyediakan data dan informasi kependudukan secara nasional mengenai pendaftaran penduduk dan pencatatan sipil pada warga yang berada di wilayah perbatasan IndonesiaMalaysia dan memberi perlindungan status hak sipil penduduk yang berada di wilayah perbatasan Indonesia-Malaysia. 2) Hambatan dan kendala yang dihadapi pemerintah Kabupaten Nunukan dalam penanganan identitas kewarganegaraan ganda yaitu rendahnya kemampuan pemerintah dilihat dari tingkat pendidikan dan kesesuain dalam menunjang tugas pelayanan, terbatasnya sarana dan fasilitas pelayanan dalam menunjang tugas pelayanan, sehingga menyebabkan keterbatasan dalam jangkauan daerah, perbatasan yang sulit dilalui karena daerah perairan, rendahnya partisipasi masyarakat dalam kepemilikan kartu tanda penduduk (KTP).
\end{abstract}

Kata Kunci : Peran Pemerintah, Identitas, Kewarganegaraan Ganda, Masyarakat Perbatasan

\section{Abstract}

This study is to determine the role of the Nunukan Regency Government in handling dual citizenship identities in Lumbis Ogong District, North Kalimantan and to determine the obstacles and obstacles faced in handling dual citizenship identities in Pebatasan, Lumbis Ogong District, North Kalimantan. This research is located in Sumentobo Village, Lumbis Ogong District. The author obtains data directly with sources, asks questions and takes direct data from relevant libraries, literature, village/sub-district documents of Lumbis Ogong and laws and regulations relating to the issue.

From the results of the research that has been carried out, it is concluded that 1) The role of the Nunukan Regency government in handling dual citizenship identities is by innovating the lightning flash program, namely the population administration service 
system for inland and border areas, implementing a ball pick-up program in the Indonesian border area Malaysia, provides national population data and information regarding population registration and civil registration of citizens living in the Indonesia-Malaysia border area and provides protection of the civil rights status of residents residing in the Indonesia-Malaysia border area. 2) Barriers and obstacles faced by the Nunukan Regency government in handling dual citizenship identities, namely the low ability of the government seen from the level of education and suitability in supporting service tasks, limited facilities and service facilities in supporting service tasks, causing limitations in regional reach, difficult borders. traversed because of water areas, low community participation in ownership of identity cards (KTP).

\section{Keywords: Role of Government, Identity, Dual Citizenship, Border Communities}

\section{Pendahuluan}

Kewarganegaraan ganda adalah sebuah status yang disematkan kepada seseorang yang secara hukum merupakan warga negara sah di beberapa negara. Kewarganegaraan ganda ada karena sejumlah negara memiliki persyaratan kewarganegaraan yang berbeda dan tidak eksklusif. Secara umum, kewarganegaraan ganda berarti orang-orang yang "memiliki" kewarganegaraan ganda, tetapi secara teknis diklaim sebagai warga negara oleh masing-masing pemerintah negara bersangkutan. Karena itu, mungkin saja bagi seseorang menjadi warga negara di satu negara atau lebih, atau bahkan tanpa kewarganegaraan.

Wacana perlunya pengaturan kewarganegaraan ganda yang tidak terbatas kian mengemuka dan menjadi isu yang terus diperjuangkan para orang Indonesia perantauan (diaspora Indonesia) di berbagai negara di belahan dunia. Wacana ini sempat digemakan terutama pada saat Kongres Diaspora pertama di Los Angeles pada tahun 2012, kemudian disusul dengan acara serupa di Wisma Indonesia, Sydney dengan mengusung tema "Forum Dual Citizenship". Acara tersebut bertujuan untuk mengawal aspirasi petisi Diaspora Indonesia tahun sebelumnya setelah diserahkannya 6000 nama dan tanda tangan di Los Angeles. Penting dicatat bahwa saat ini diperkirakan lebih dari sekitar 8 juta warga negara Indonesia tersebar di 5 (lima) benua, dan mereka berdomisili di kurang lebih sekitar 90 negara dan sebanyak 4,6 juta dari antara mereka tetap mempertahankan Kewarganegaraan Indonesia.

Ada beberapa dampak kewarganegaraan ganda sebagai berikut:

Dampak positif:

1. Jika Indonesia memiliki seorang tenaga ahli yang sedang berada di luar negeri, Indonesia dapat sewaktu-waktu memanggil orang tersebut untuk memenuhi kewajibannya sebagai warga negara, mengabdi kepada Indonesia.

2. Warga negara yang sedang mencari pekerjaan dapat dengan mudah mencari pekerjaan diluar negeri tanpa terkendala masalah imigrasi.

3. Membuat warga negara lebih bebas berbisnis dengan negara lain.

4. Kewarganegaraan ganda bisa melindungi anak dari pasangan yang berbeda kewarganegaraan, karena dengan demikian orang tua mereka tidak bisa dideportasi akibat masalah hukum. 
Dampak negatif:

1. Sulit untuk mengungkap pelaku kriminal yang kabur ke negara keduanya

2. Dapat dicurigai sebagai pengkhianat jika kedua negara tersebut sedang melakukan perang satu sama lain.

3. Memudahkan warga negara lain untuk mendapatkan status kewarganegaraan Indonesia.

4. Dapat membuat terancamnya keamanan dan kedaulatan negara/mengklaim negara kita.

Lumbis Ogong adalah salah satu Kecamatan di Kabupaten Nunukan, Provinsi Kalimantan Utara, Indonesia. Kecamatan ini bersama dengan kecamatan pemekaran Lumbis Hulu merupakan hasil pemekaran dari Kecamatan Lumbis Ogung pada tahun 2019. Kecamatan Lumbis Ogong adalah Kecamatan yang memiliki jarak tempuh yang sangat jauh untuk sampai ke ibu kota Kabupaten Nunukan. Lumbis Ogong berjarak dua hari perjalanan ke pusat pemerintahan Nunukan melintasi hutan dan harus naik perahu, sedangkan segala urusan pemerintahan harus diselesaikan di kota yang terpusat di Pulau Nunukan.

Dengan kondisi demikian, tidak mengherankan warga Lumbis Ogong memilih jalur "pintu belakang" yaitu Malaysia untuk memenuhi kebutuhan hidup. Ke perbatasan, hanya 15 menit jalan kaki, dimana 1 jam setelahnya mendapati jalan tol yang menghubung Pensiangan hingga Keningau Sabah, Malaysia. Ribuan warga Lumbis Ogong hidup berladang di area yang berbatasan langsung dengan Malaysia. Status kawasan 154 ribu hektar di Lumbis Ogong itu dinyatakan outstanding boundary problem (OBP) antara Pemerintah Indonesia dan Malaysia. Tujuh dari 21 desa yang masuk kawasan OBP ini berada di sekitar Lumbis Ogong. Hampir semua kebutuhan warga Lumbis Ogong asalnya dari Malaysia, semisal sembako, alat rumah tangga, BBM hingga layanan kesehatan (https://www.benarnews.org/indonesian/berita/lumbis-Ogong-html).

Sejumlah daerah di Kecamatan Kalimantan Utara yang berbatasan dengan Malaysia, penduduknya ternyata berkewarganegaraan ganda, contohnya seperti di Kecamatan Lumbis Ogong ini warganya memiliki dua identitas kewarganegaraan yakni Indonesia dan Malaysia. Dari hampir 18.000 jiwa jumlah penduduk pada Kecamatan tersebut, diperkirakan 50 persen memiliki kartu tanda penduduk (KTP) Indonesia dan Identity Card (IC) Malaysia, hal ini terjadi dikarenakan Kecamatan Lumbis Ogong berbatasan langsung dengan Negeri Sarawak, Malaysia, sehingga akses keluar masuknya sangat mudah. Kartu identitas sebagai warga negara Malaysia ini pun sangat mudah didapatkan warga, asalkan ada jaminan keluarga yang telah lebih dulu menjadi warga negara Malaysia.

Selain letak wilayah yang berbatasan dengan Negeri Sarawak Malaysia, sulitnya akses jalan dan transportasi menuju ke Kabupaten Nunukan, menyebabkan warga di perbatasan Lumbis Ogong kesulitan mengurus KTP Indonesia. Sedangkan akses jarak tempuh ke Malaysia lebih mudah dijangkau, sehingga membuat warga mudah untuk dapat memiliki kartu identitas Malaysia, hal ini pula memperkuat godaan warga Lumbis Ogong untuk beralih kewarganegaraan atau memiliki KTP ganda, serta membuat mereka bergantung hampir 100\% ke Malaysia. Malaysia pun juga mempermudah urusan mereka di Malaysia, hanya dengan mengantongi KTP Malaysia, warga perbatasan bisa mendapatkan pendidikan dan berobat gratis di 
Malaysia diakses pada tanggal 26 Agustus 2019 melalui https://nasional.kompas.com/read/Ini.Alasan.Warga.Perbatasan.Mempunyai.KTP. Malaysia).

Fenomena warga perbatasan memiliki KTP atau identitas ganda merupakan kisah lama yang dilupakan. Dari 200 kepala keluarga di perbatasan Kecamatan Lumbis Pansingan, saat ini tinggal 70 kepala keluarga saja yang bertahan. Salah satu permasalahan bagi masyarakat di kawasan perbatasan pedalaman tersebut adalah kepemilikan dokumen administrasi kependudukan (adminduk). Masyarakat yang tinggal di kawasan tersebut harus menempuh perjalanan jauh dan mengeluarkan biaya yang sangat mahal untuk dapat mengurus secara mandiri administrasi kependudukan di kantor-kantor Dinas Kependudukan dan Catatan Sipil (Disdukcapil) yang berada di ibukota Kabupaten.

Banyaknya penduduk rentan yang belum memiliki dokumen adminduk, Disdukcapil Provinsi Kalimantan Utara pun melahirkan inovasi guna menjangkau warga di perbatasan dalam pengurusan identitas yaitu Sistem Pelayanan Administrasi Kependudukan untuk Wilayah Pedalaman dan Perbatasan atau Sipelandukilat. Inovasi ini merupakan penggabungan kata pelanduk atau kancil hewan lincah dan mampu beradaptasi di wilayah hutan pedalaman Kalimantan dan kilat. Sipelandukilat memfasilitasi Disdukcapil Kabupaten yang memiliki daerah pedalaman dan perbatasan dalam mengatasi permasalahan kepemilikan dokumen adminduk dengan mendatangi langsung wilayah perbatasan.

Inovasi ini adalah upaya pemerintah derah khususnya Kabupaten Nunukan melakukan pelayanan publik secara cepat dan lincah, khusus difokuskan untuk melayani masyarakat yang terisolasi, yang tinggal tersebar tidak merata di wilayah pedalaman dan perbatasan Kalimantan Utara yaitu dengan melaksanakan program jemput bola yang berada di wilayah perbatasan Indonesia-Malaysia sehingga terpenuhi dalam pelayanan khusus perekaman e-KTP dan identitas kependudukan lainnya, sehingga mengantisipasi terjadinya kewarganegaraan ganda.

\section{Metode Penelitian}

Jenis penelitian yang digunakan pada penelitian ini adalah jenis penelitian kualitatif. Metode penelitian kualitatif sebagai proses penelitian yang menghasilkan data deskripstif berupa kata-kata tertulis/lisan dari orang-orang dan perilaku yang dapat di amati (Moleong, 2014: 63). Sedangkan menurut Nawawi (2011: 63) penelitian kualitatif diartikan sebagai prosedur pemecahan masalah yang diselidiki dengan menggambarkan atau melukiskan keadaan subjek dan objek penelitian (seseorang, lembaga, masyarakat dan lain-lain). Berdasarkan metode penelitian di atas, maka penelitian yang dilakukan penulis bertujuan untuk menggambarkan peranan Pemerintah Kabupaten Nunukan dalam menangani identitas kewarganegaraan ganda di Kecamatan Lumbis Ogong Kalimantan Utara.

Dalam penelitian ini sumber data yang digunakan adalah sumber data primer dan sumber data sekunder. Teknik pengambilan informan pada penelitian kualitatif ini menggunakan teknik sampling (purposive sampling), sehingga sampel yang dimbil berdasarkan tujuan yang telah ditetapkan. Informan yang purposive diharapkan mampu memberikan informasi yang diinginkan namun tidak menggeneralisasi dari 
populasi. Metode pengambilan sampel tidak acak, dimana sampel dipilih berdasarkan pertimbangan-pertimbangan tertentu (Bungin, 2007:50). Dalam penelitian ini sumber informan yang dianggap peneliti dapat memberikan informasi yaitu: aparat dinas kependudukan dan pencatatan sipil Kecamatan Lumbis Ogong, aparat Kepala Desa Sumentobol dan mayarakat di Desa Sumentobol. Penelitian kualitatif menurut Moleong (2014:70) jenis penelitian lebih mengarah kepada katakata dan tindakan. Adapun teknik pengumpulan data yang digunakan di dalam proses penelitian ini adalah Observasi yaitu melakukan pengamatan secara langsung ke objek penelitian untuk melihat dari dekat kegiatan yang dilakukan, yaitu tentnag peran pemerintah dalam penanganan identitas kewarganegaraan ganda di perbatasan Kecamatan Lumbis Ogong Kabupaten Nunukan Kalimantan Utara. Wawancara, digunakan untuk memperoleh informasi langsung dari sumbernya. Pewawancara adalah pengumpul informasi yang diharapkan dapat meyampaikan pertanyaan dengan jelas dan kemudian menulis semua jawaban dari pemberi informasi (Informan). Dokumentasi, teknik pengumpulan data dengan menggunakan arsip atau dokumen sebagai sumber data yang dapat diperinci dengan jalan melihat, mencatat dan mengabadikan dalam gambar. Dokumentasi biasanya berupa foto-foto, arsip, surat keputusan serta tulisan-tulisan kejadian dimasa lalu yang berisi tentang kejadian apa yang dilakukan oleh subyek penelitian secara langsung maupun tidak langsung. Adapun teknik analisa data kualitatif dilaksanakan melalui beberapa tahap, antara lain Pengumpulan Data, Reduksi Data, Kategori dan Interpretasi Data Setelah interpretasi data selesai, langkah selanjutnya adalah melakukan uji validitas dengan cara Triangulasi, yaitu proses pengecekan ulang terhadap tingkat keabsahan atau kebenaran data yang diperoleh. Langkah yang selanjutnya yaitu peneliti melakukan penarikan kesimpulan. Kesimpulan awal yang dikemukakan masih bersifat sementara, dan dapat berubah blia tidak ditemukan bukti-bukti yang kuat yang mendukung pada tahap pengumpulan data berikutnya. Kesimpulan dalam penelitian kualitatif akan dapat menjawab rumusan masalah yang dirumuskan sejak awal, tetapi mungkin juga tidak sebab rumusan masalah dalam penelitian kualitatif masih bersifat sementara dan akan berkembang setelah penelitian di lapangan. Kesimpulan dalam penelitian kualitatif merupakan temuan baru yang belum pernah ada. Temuan dapat berupa deskripsi atau gambaran suatu objek yang sebelumnya masih remang-remang, sehingga setelah diteliti menjadi jelas.

\section{Hasil Dan Pembahasan}

\section{Peran Pemerintah Kabupaten Nunukan dalam penanganan identitas} kewarganegaraan ganda di Kecamatan Lumbis Ogong Kalimantan Utara.

Kewarganegaraan ganda sejumlah warga perbatasan Republik IndonesiaMalaysia di Kabupaten Nunukan dinilai sebagai potensi ancaman yang harus segera ditanggulangi, khususnya perbatasan di Desa Sumentobol Kecamatan Lumbis Ogong Kabupaten Nunukan, Kalimantan Utara. Masyarakat Desa Sumentobol adalah masyarakat yang berada dibagian Utara desa Kalimantan yang berbatasan langsung dengan negara Malaysia. Pada umumnya masyarakat di desa Sumentobol merupakan masyarakat pendatang, mayoritas penduduk 
berasal dari Sulawesi selatan. Kondisi teritorial yang sangat dekat dengan negara Malaysia, bahkan berbatasan langsung, membuat permasalahan-permasalaham yang melibatkan kedua negara kerap bermunculan.

Adapun alasan warga masyarakat perbatasan desa Sumentobol memiliki kewargaangaraan ganda, semua berawal dari permasalahan-permasalahan yang di alami masyarakat di desa Sumentobol selama ini, antara lain keterisolasian, keterbelakangan, kemiskinan, mahalnya harga barang dan jasa, keterbatasan prasarana dan sarana pelayanan publik (infrastruktur), rendahnya kualitas SDM pada umumnya, penyebaran penduduk yang tidak merata, serta terjadinya penumpukan TKI akibat adanya deportasi dari Malaysia. Potensi sumber daya alam yang dimiliki di wilayah ini cukup melimpah, namun hingga saat ini relatif belum dimanfaatkan secara optimal. Di sisi lain, terdapat berbagai persoalan yang mendesak untuk ditangani karena besarnya dampak dan kerugian yang dapat ditimbulkan. Ketertinggalan secara ekonomi yang dirasakan oleh masyarakat perbatasan Kalimantan Utara seperti halnya di desa Sumentobol juga dipicu oleh minimnya infrastruktur dan aksesibilitas yang tidak memadai, seperti jaringan jalan dan angkutan perhubungan darat maupun sungai masih sangat terbatas, prasarana dan sarana komunikasi seperti pemancar atau transmisi radio dan televisi serta sarana telepon relatif minim, ketersediaan sarana dasar sosial dan ekonomi seperti pusat kesehatan masyarakat, sekolah, dan pasar juga sangat terbatas. Sebagai sebuah kawasan yang baru berkembang, infrastruktur di perbatasan Sumentobol masih dapat dikatakan tertinggal jika dibanding dengan wilayah lainnya, terutama dengan Tawau, Sabah, Malaysia. Desa Sumentobol sebagai wilayah yang tergolong daerah tertinggal mempunyai keterbatasan infrastruktur, seperti sarana perhubungan, komunikasi, penyediaan air bersih, sarana pendidikan, dan sarana kesehatan. Prasarana dan sarana kesehatan yang ada di wilayah desa Sumentobol saat ini hanya ada puskesmas ditiap-tiap kecamataan, dan beberapa posyandu, serta bidan yang terbatas dan tidak merata yang hanya ada di beberapa kecamatan saja. Hal ini merupakan permasalahan sendiri bagi penduduk di desa Sumentobol dalam mewujudkan kesehatan keluarga dan masyarakat.

Kewarganegaran ganda bagi masyarakat desa Sumentobol merupakan suatu hal yang biasa-biasa saja dikalangan mereka. Kurangnya perhatian dari pemerintah yang membuat masyarakan mencari alternatif lain untuk bertahan hidup dan negara Malaysia yang dianggap bisa untuk memenuhi itu semua. Dari permasalahan-permasalahan tersebut memicu munculnya masyarakat yang memiliki kewarganegaraan ganda di Desa Sumentobol Kecamatan Lumbis Ogong Kabupaten Nunukan yakni sebagai warga negara Indonesia dan warga negara Malaysia. Ketergantungan masyarakat pada negara tetangga dapat mengurangi rasa kebangsaan dan nasionalisme. Mereka akan lebih mementingkan kebutuhan ekonomi daripada memperhatikan kedudukannya sebagai warga negara Indonesia. Hal ini tampak dari informasi yang diperoleh bahwa beberapa penduduk Sumentobol, terutama yang dekat dengan perbatasan mempunyai ID ganda. Alasan mereka adalah untuk kemudahan hubungan dengan masyarakat negara tetangga yang dirasakan memberikan banyak keuntungan. Sementara itu, akses komunikasi dan transportasi ke wilayah 
Indonesia masih kurang memadai, sehingga sebagian besar penduduk seolaholah kurang menyatu dan berinteraksi secara intensif dengan penduduk lainnya di wilayah Indonesia. Hal ini menjadikan Sumentobol tertinggal dalam berbagai pembangunan, baik pembangunan fisik maupun non fisik.

Menyikapi kewarganegaran ganda seperti memiliki warga negra Indonesia dan Malaysia, bagi warga Desa Sumentobol merupakan bentuk perjuangan hidup dalam memenuhi kebutuhan. Dikarenakan jika bergantung pada negara sejauh ini tidak ada perhatian yang nyata kepada masyarakat di perbatasan. Untuk mengatasi permasalahan-permasalahan kewarganegaraan ganda yang di miliki masyarakat desa Sumentobol di butuhkan peran pemerintah dalam penanganan identitas kewarganegaraan ganda di Kecamatan Lumbis Ogong Kalimantan Utara, diantaranya:

\section{Melakukan Inovasi Program Sipelanduk Kilat Yaitu Sistem Pelayanan Administrasi Kependudukan Untuk Wilayah Pedalaman Dan Perbatasan.}

Salah satu permasalahan bagi masyarakat di kawasan perbatasan pedalaman adalah kepemilikan dokumen administrasi kependudukan (adminduk). Masyarakat yang tinggal di kawasan tersebut harus menempuh perjalanan jauh dan mengeluarkan biaya yang sangat mahal untuk dapat mengurus secara mandiri administrasi kependudukan di kantor-kantor Dinas Kependudukan dan Catatan Sipil (Disdukcapil) yang berada di ibukota Kabupaten. Banyaknya penduduk rentan yang belum memilki dokumen adminduk, Disdukcapil Provinsi Kalimantan Utara melahirkan inovasi Sistem Pelayanan Administrasi Kependudukan untuk Wilayah Pedalaman dan Perbatasan atau Sipelandukilat. Inovasi ini merupakan penggabungan kata pelanduk atau kancil - hewan lincah dan mampu beradaptasi di wilayah hutan pedalaman Kalimantan - dan kilat. Sipelandukilat memfasilitasi Disdukcapil kabupaten yang memiliki daerah pedalaman dan perbatasan dalam mengatasi permasalahan kepemilikan dokumen adminduk dengan mendatangi langsung wilayah perbatasan. Inovasi ini adalah upaya pemerintah dalam melakukan pelayanan publik secara cepat dan lincah, khusus difokuskan untuk melayani masyarakat yang terisolasi, yang tinggal tersebar tidak merata di wilayah pedalaman dan perbatasan Kalimantan Utara. Sipelandukilat memberikan 22 pelayanan administrasi kepada masyarakat di perbatasan, seperti KTP-el, akte kelahiran, dan kartu keluarga. Pelayanan adminduk dengan prinsip tepat, akurat, lengkap, dan gratis ini berfokus pada wanita, anak-anak, orang tua, serta penyandang disabilitas yang seringkali kesulitan untuk pergi ke ibukota kabupaten untuk mengakses pelayanan adminduk.

Sipelanduk kilat sebagai inovasi dalam pengadaan dokumen adminduk memiliki potensi besar untuk dapat diterapkan dan dimanfaatkan di provinsi lain yang memiliki garis perbatasan dengan negara lain seperti Kalimantan Utara, terutama di daerah-daerah yang terisolasi, jauh, dan sulit dijangkau. Dengan inovasi dalam pelayanan dokumen adminduk, maka penduduk di wilayah perbatasan dapat merasakan kehadiran negara di garis 
perbatasan dengan bukti kepemilikan identitas sebagai WNI. Kalimantan Utara merupakan provinsi yang tercepat dan terbaik dalam pelayanan kependudukan. Hingga saat ini sekitar 4.000 warga perbatasan Kabupaten Nunukan telah melakukan perekaman E-KTP masih menunggu persetujuan Kemendagri untuk pencetakan kartu. 


\section{Melaksanakan Program Jemput Bola Yang Berada Di Wilayah Perbatasan Indonesia-Malaysia}

Meskipun program Sipelanduk Kilat ini mendapatkan partisipasi dan rasa antusiasme yang besar dari masyarakat, program ini belum seluruhnya berjalan dengan baik karena terhambat oleh keadaan dan waktu. Masyarakat yang bekerja sebagai Pegawai Negeri Sipil, Pegawai Swasta dan buruh harian tidak mudah dalam membagi waktu untuk berpastisipasi mengikuti proses perekaman data. Rata-rata PNS/Swasta dan buruh harian tidak bisa berkumpul pada saat yang ditentukan karena mereka terhambat oleh pekerjaan yang menyita waktu mereka.

Melihat kendala-kendala yang terjadi dilapangan, maka Kepala Disdukcapil Kabupaten Nunukan memberikan beberapa solusi untuk memecahkan masalah tersebut untuk mengejar selesainya pelaksanaan proses perekaman data kependudukan dengan mengeluarkan kebijakan diluar ketentuan kebijakan Pemerintah Pusat. Kebijakan yang diinstruksikan oleh Kepala Disdukcapil Kabupaten Nunukan dalah dengan menggunakan sistem jemput bola dimana aparatur yang telah ditunjuk oleh Kepala Disduk Kabupaten Nunukan terjun langsung kelapangan menjemput masyarakat yang berada dipedesaan dengan melihat jangkauan jarak jauh Desa dengan Kecamatan untuk memberikan pelayanan dengan durasi waktu dari pukul 08.00 sampai dengan 17.00 . Solusi tersebut telah disampaikan informasinya kepada seluruh masyarakat oleh elemen-elemen masyarakat Kecamatan dan Desa yang akan dilakukan sistem jemput bola tersebut. Solusi tersebut pun telah dilaksanakan oleh Disdukcapil Kabupaten Nunukan dan telah berhasil membuat masyarakat melakukan perekaman data kependudukan. Seperti yang dikatakan oleh kepala Kecamatan Lumbis Ogong menjelaskan bahwa dengan layanan jemput bola pelayanan dokumen adminduk ini, masyarakat bisa langsung mendapatkan dokumen yang mereka butuhkan dalam hitungan jam. Karena, selain mengedepankan kecepatan, Sipelandukilat ini memberikan pelayanan secara merata, gratis, dan anti-pungutan liar. Layanan jemput bola yang dilakukan oleh Tim JPC ini langsung dilakukan di tempat dan dibuka untuk semua layanan administrasi kependudukan, diantaranya cetak kartu keluarga, surat pindah, ktp elektronik, kartu identitas anak, biodata WNI, akta kelahiran, akta kematian, akta perkawinan, akta perceraian, dan seluruh dokumen administrasi kependudukan lainnya dan langsung dapat di cetak di tempat layanan. Layanan ini dipandang sangat penting dan bermanfaat bagi warga karena tentunya sangat membantu warga untuk mempermudah mendapatkan kelengkapan dokumen kependudukan mereka. Bagi warga penyandang disabilitas, Tim JPC Dukcapil Nunukan juga melakukan pelayanan langsung ke rumah warga untuk dilakukan proses perekaman dan penerbitan dokumen yang diminta oleh warga. Pelayanan jemput bola oleh Tim JPC juga dilakukan di hari libur yakni sabtu maupun minggu, sehingga juga diharapkan akan dapat membantu warga yang memang hanya memiliki kesempatan mengurus dokumen kependudukannya di hari libur kerja saja. 
3. Menyediakan Data Dan Informasi Kependudukan Secara Nasional Mengenai Pendaftaran Penduduk Dan Pencatatan Sipil Pada Warga Yang Berada Di Wilayah Perbatasan Indonesia-Malaysia.

Disdukcapil yang turun ke lapangan pun diharuskan memberikan pemahaman kepada masyarakat mengenai pentingnya kepemilikan identitas sebagai Warga Negara Indonesia (WNI). Sosialisasi untuk mengenalkan pemahaman ini dilakukan ke seluruh dusun dan kampung yang menjadi sasaran dari program ini sebelum kegiatan pelayanan adminduk dilakukan. Sosialisasi ini merupakan sebuah pemahaman baru untuk menambah khasanah berpikir, agar para pelaku dapat memberikan pelayanan yang baik kepada masyarakat. Sosialisasi ini penting, walaupun yang dibahas nantinya adalah kawasan perbatasan, namun kecamatan lain juga harus dapat memahami dan menerapkan pelayanan penerbitan dokumen kependudukan. Pemerintah berharap, perangkat daerah khususnya para Camat, Lurah, dan Kepala Desa dapat menyerap apa yang disampaikan oleh pihak direktorat. Sehingga nantinya, para perangkat daerah dapat menerapkan informasi dan mentransfer pemahaman yang di dapat dari Ditjen Dukcapil Kemendagri dalam tugasnya dilansir dari (http://infopublik.id/read/190496/sosialisasipelayanan-penerbitan-dokumen-kependudukan-di-kawasanperbatasan.html)

\section{Memberi Perlindungan Status Hak Sipil Penduduk Yang Berada Di Wilayah Perbatasan Indonesia-Malaysia}

Sistem Pelayanan Administrasi Kependudukan untuk Wilayah Pedalaman dan Perbatasan ini sudah dijalankan sejak Februari 2017, Sipelandukilat telah menyambangi delapan wilayah serta tujuh kecamatan dan telah mencetak dokumen adminduk sebanyak 11.446 dokumen. Sehingga masyarakat di perbatasan memiliki kepastian dan perlindungan hukum melalui kepemilikan dokumen adminduk. Selain itu, inovasi ini juga sebagai perwujudan Nawacita Presiden Joko Widodo ketiga, yakni membangun Indonesia dari pinggiran dengan memperkuat daerah-daerah dan pedesaan. Perlindungan status hak sipil penduduk yang berada di wilayah perbatasan di lindungi berdasarkan Undang-Undang RI No 23 Tahun 2006 tentang Administrasi Kependudukan yaitu bahwa Negara Kesatuan Republik Indonesia berdasarkan Pancasila dan Undang-Undang Dasar Negara Republik Indonesia Tahun 1945 pada hakikatnya berkewajiban memberikan perlindungan dan pengakuan terhadap penentuan status pribadi dan status hukum atas setiap Peristiwa Kependudukan dan Peristiwa Penting yang dialami oleh Penduduk Indonesia yang berada di dalam dan/atau di luar wilayah Negara Kesatuan Republik Indonesia. Untuk menjaga hak asasi manusia tetap terpenuhi dalam bidang administrasi kependudukan, maka Pemerintah Kabupaten Nunukan mendesain sebuah peraturan daerah yang mengatur tentang administrasi kependudukan yang di tuangkan dalam Peraturan Daerah Kabupaten Nunukan Nomor 6 Tahun 2011 tentang Penyelenggaraan Administrasi Kependudukan. Upaya pemerintah Kabupaten Nunukan dalam Perlindungan status hak sipil penduduk yang berada di wilayah perbatasan ini di harapkan dapat melindung masyarakat perbatasan 
dalam pemilika kependudukan WNI serta dapat menghindari kewarganegaraan ganda.

\section{Hambatan dan kendala yang dihadapi Pemerintah Kabupaten Nunukan dalam penanganan identitas kewarganegaraan ganda di Kecamatan Lumbis Ogong Kalimantan Utara.}

\section{Rendahnya kemampuan pemerintah dilihat dari tingkat pendidikan dan ketrampilan/keahlian untuk menunjang tugas pelayanan}

Kesalahan administrasi kependudukan juga tidak lepas dari permasalahan kepegawai tingkat desa di tiap-tiap kecamatan, rendahnya tingkat pendidikan pegawai desa ditiap-tiap kecamatan dianggap sebagai salah satu penyebab masalah pengadministrasian kependudukan dapat terjadi. Hal ini terjadi karena dampak dari kurangnya falitas pendidikan yang terbangun ditiap-tiap kecamatan di Desa Sumentobol.

Kesalahan administrasi kependudukan sulit untuk di diatasi di negara Indonesia ini, melihat Indonesia adalah negara yang besar dan memiliki pulau-pulau serta jumlah penduduk yang banyak. Hal ini menjadi catatan tersendiri bagi dinas catatan sipil Kabupaten Nunukan. Karena kejelasan kewarganegaraan di Indonesia hanya mengakui satu kewarganegaraan, yakni kewarganegaraan Indonesia yang sesuai dengan undang-undang kita. Selain itu kewarganegaraan juga sangat berpengaruh dalam pengakuan terhadap negara. Karna itu tidaklah terlalu sulit bagi dinas catatan sipil untuk lebih berkordinasi dengan phaik aparat camat maupuan ketua Desa Sumentobol. Meminta kiranya Untuk lebih selektif dalam memili tenaga pembantu dalam pengumpulan berkas-berkas sehingga informasi kependudukan bisa tepat sasaran. Belum tercapainya penyelesaian administrai kependudukan di Kabupaten Nunukan menemui berbagai kendala. Pertama, Terbatasnya sarana dari fasilitas yang menunjang dalam pelayanan. Dalam hal pelaksanaan penerapan sipelanduk kilat, ada 1 (satu) wilayah yang secara geografis merupakan daerah rawa/air yang tidak dapat dijangkau oleh transportasi darat seperti kendaraan roda 4, dimana wilayah tersebut merupakan daerah yang berbatasan dengan Provinsi Kalimantan Tengah. Selain itu sebaran penduduk yang masih terisolir, yakni merupakan daerah yang perlu penanganan dan perhatian khusus dalam pelayanan kependudukan mendatang. Kondisi diatas menjadi kendala sarana transportasi yang di hadapi karena memang kondisi geografis Kabupaten Nunukan pada beberapa wilayah kecamatan tertentu terdapat daerah rawa dan danau, begitupun mengenai sarana mutu. Kedua, Rendahnya Partisipasi Masyarakat. Selain kendala-kendala di atas, tingkat kesadaran masyarakat untuk kepemilikan kartu tanda penduduk (KTP) juga menjadi kendala dalam melaksanakan program sipelandukkilat di Kabupaten Nunukan Kalimantan Utara diantaranya kondisi lingkungan yang dialami masyarakat yang ada di perbatasan saat ini sulit akses jalan dan transortasi yang mahal, kebanyakan area tersebut di aliri sungai, sebab itu masyarakat kurang berparsitipasi. Berdasarkan data hasil wawancara dengan Bidang pendaftaran penduduk, 
sebanyak 70 persen tingkat partisipasi spontan dari masyarakat dalam pengurusan kartu tanda penduduk rendah. Sedangkan menurut dinas pendaftaran penduduk, hanya terdapat beberapa orang saja yang berpartisipasi langsung yaitu masyarakat yang memahami pentingnya kartu keluarga dan kartu tanda penduduk dan memiliki jarak tempat tinggal yang tidak jauh dengan kantor pengurusan.

Munculnya masyarakat yang memiliki dua kewarganegaraan di Desa Sumentobol Kabupaten Nunukan Kalimantan Utara salah satu penyebabnya adalah kesalahan dalam pengadministrasian penduduk di Kabupaten Nunukan. Kabupaten Nunukan merupakan pintu gerbang keluar masuknya masyarakat dari Indonesia ke Malaysia ataupun sebaliknya. Termasuk didalamnya Desa Sumentobol yang memiliki jalur keluar masuk yang sering di lalui dan mudah dilewati. Bukan hanya Malaysia saja bahkan negara-negara Asia Tenggara lainnya seperti Filipina dan Brunai Darusalam kerap bermunculan. Serta bukan hanya masyarakat lokal Kabupaten Nunukan saja yang sering melintas antar negara banyak dari pendatang yang mayoritas di dominasi dari Sulawesi selatan kerap datang melintas lewat Kabupaten Nunukan, bahkan tidak sedikit dari mereka yang pada akhirnya menetap dan berdomisili di Kabupaten Nunukan. Hal ini kerap membuat dinas catatan sipil kabupaten nunukan kerap kecolongan dalam memberikan NIK ke masyarakat. Pasalnya ada dari mereka yang sebelumnya sudah menjadi warga negaraan Malaysia dan masih mengurus kependudukan di Indonesia. 


\section{Kesimpulan}

\section{A. Kesimpulan}

Kesimpulan dari hasil penelitian tentang kewarganegaraan ganda di Kabupaten Nunukan yaitu:

1. Peran pemerintah Kabupaten Nunukan dalam penanganan identitas kewarganegaraan ganda di desa Sumentobol Kecamatan Lumbis Ogong Kalimantan Utara:

a. Melakukan inovasi program si pelanduk kilat yaitu sistem pelayananm administrasi kependudukan untuk wilayah pedalaman dan perbatasan atau Sipelandukilat. Dengan inovasi ini pemerintah daerah dalam melakukan pelayanan publik dapat secara cepat dan lincah, khusus difokuskan untuk melayani masyarakat yang terisolasi, yang tinggal tersebar tidak merata di wilayah pedalaman dan perbatasan Kalimantan Utara

b. Melaksanakan program jemput bola yang berada di wilayah perbatasan Indonesia-Malaysia dengan layanan jemput bola pelayanan dokumen adminduk ini, masyarakat bisa langsung mendapatkan dokumen yang mereka butuhkan dalam hitungan jam. Karena, selain mengedepankan kecepatan, Sipelandukilat ini memberikan pelayanan secara merata, gratis, dan anti-pungutan liar.

c. Menyediakan data dan informasi kependudukan secara nasional mengenai pendaftaran penduduk dan pencatatan sipil pada warga yang berada di wilayah perbatasan Indonesia-Malaysia. Dengan selalu memberkan informasi pelayanan di tiap-tiap kecamatan, sehingga masyarakat bisa mengunjungi sesuai tanggal yang sudah ditentukan dengan membawa persyaratan kependudukan.

d. Memberi perlindungan status hak sipil penduduk yang berada di wilayah perbatasan Indonesia-Malaysia. Dengan Upaya pemerintah Kabupaten Nunukan dalam Perlindungan status hak sipil penduduk yang berada di wilayah perbatasan ini di harapkan dapat melindung masyarakat perbatasan dalam pemilika kependudukan WNI serta dapat menghindari kewarganegaraan ganda Peraturan Daerah Kabupaten Nunukan Nomor 6 Tahun 2011 tentang Penyelenggaraan Administrasi Kependudukan.

2. Hambatan dan kendala yang dihadapi pemerintah Kabupaten Nunukan dalam penanganan identitas kewarganegaraan ganda di desa Sumentobol Kecamatan Lumbis Ogong Kalimantan Utara:

a. Rendahnya kemampuan pemerintah dilihat dari tingkat pendidikan dan kesesuain dalam menunjang tugas pelayanan.

b. Terbatasnya sarana dan fasilitas pelayanan dalam menunjang tugas pelayanan, sehingga menyebabkan keterbatasan dalam jangkauan daerah, perbatasan yang sulit dilalui karena daerah perairan.

c. Rendahnya partisipasi masyarakat dalam kepemilikan kartu tanda penduduk (KTP), diantaranya kondisi lingkungan yang dialami masyarakat yang ada di perbatasan saat ini sulit akses jalan dan transortasi yang mahal, kebanyakan area tersebut di aliri sungai, sebab itu masyarakat kurang berparsitipasi. 


\section{B. Saran}

1. Kewarganegaraan ganda yang di miliki masyarakat di perbatasan Kabupaten Nunukan menjelaskan bahwa masyarakat apatisme terhadap negara yang berdampak pada menduakan negara yang mereka miliki hanya sekedar simbois belaka. Hilangnya pelegetimasian masyarakat terhadap negara sangat berpengaruh terhadap jalannya roda-roda pemerintahan.

2. Pemenuhan kebutahan pokok yang harus sampai ke pelosok-pelosok nusantara, masih belum maksimal hingga saat ini. Serta peningkatan ekonomi yang sejauh ini masih tidak dirasakan oleh masyarakat di negara sendiri yang membuat ketergantungan dengan negara lain, hal ini menyebabkan masyarakat perbatasan memilih kewarganegaraan ganda, demi mendapatkan kemudahan bahan pokok dari Negara sebrang.

3. Administarasi kependudukan yang harus di benahi, serta prosedural tanpa di wakili harus diterapkan guna menghindari cacatnya keakuratan data penduduk. 


\section{Daftar Pustaka}

Alwi Hasan, dkk. 2005. Kamus Besar Bahasa Indonesia. Jakarta: Departemen. Pendidikan Nasional Balai Pustaka.

Badan Pusat Statistik. 2020. Kecamatan Nunukan Dalam Angka Tahun 2017. Nunukan: BPS Kabupaten Nunukan.

Bungin, Burhan. 2007. Penelitian Kualitatif. Jakarta: Kencana.

J. Moleong, Lexy. 2014. Metode Penelitian Kualitatif, Edisi Revisi. Bandung: PT Remaja Rosdakarya.

KBBI. 2005. Kamus Besar Bahasa Indonesia. Jakarta: PT Penerbitan Dan Percetakan.

Lulus Udjiwati. 2016. Status Legal Formal (Bi Patride) Kewarganegaraan Anak Dari Perkawinan Campuran Kewarganegaraan. Yustisia Merdeka.

Miftah Thoha. 2003. Perilaku Organisasi: Konsep Dasar dan Aplikasinya. Jakarta: PT. Raya Grafindo Persada.

Nawawi, Hadari. 2011. Manajemen Sumber Daya manusia. Yogyakarta: Gadjah. Mada University Press.

Ndraha, Taliziduhu. 1987. Pembangunan Masyarakat. Jakarta. Rineka Cipta.

Peter Mahmud Marzuki. 2011. Penelitian Hukum. Cet. 7. Jakarta: Kencana.

Soerjono Soekanto. 2010. Pengantar Penelitian Hukum. Jakarta: Univ. Indonesia.

Sondang P Siagian. 2003. Manajemen Sumber Daya Manusia. Edisi satu, cetakan kesepuluh. Jakarta : Bumi Aksara.

Tjandra, Riawan W,dkk. 2005. Peningkatan Kapasitas Pemda dalam Pelayanan. Publik. Yogyakarta: Pembaruan.

\section{Undang-Undang}

Peraturan Daerah (PERDA) Kabupaten Nunukan Nomor 23 Tahun 2011 Pembentukan, Susunan Organisasi Dan Tata Kerja Badan Pengelola Perbatasan Daerah Kabupaten Nunukan.

Peraturan Pemerintah Republik Indonesia Nomor 2 Tahun 2007 Tentang Tata Cara Memperoleh, Kehilangan, Pembatalan, Dan Memperoleh Kembali Kewarganegaraan Republik Indonesia.

Peraturan Presiden Nomor 25 Tahun 2008 Tentang Persyaratan Dan Tata Cara Pendaftaran Penduduk dan Pencatatan Sipil.

Surat Keputusan Bupati Nunukan Nomor 08 Tahun 2003 tentang penyeleggaraan pendaftaran penduduk, pencatatan sipil dan pengelolaan informasi penduduk.

Undang-Undang Dasar Negara Republik Indonesia Tahun 1945.

Undang-undang No. 23 Tahun 2006 tentang Administrasi Kependudukan.

Undang-Undang Nomor 12 Tahun 2006 tentang Kewarganegaraan Republik Indonesia.

Undang-Undang Nomor 23 Tahun 2014 tentang Pemerintahan Daerah.

Undang-Undang Nomor 43 Tahun 2008 tentang Wilayah Negara (Lembaran Negara Republik Indonesia Tahun 2008 Nomor 177, Tambahan Lembaran Negara Republik Indonesia Nomor 4925. 